\section{DIGITAL COMMONS \\ @ UNIVERSITY OF SOUTH FLORIDA}

\section{ABO: Interactive Journal for Women in the Arts, 1640-1830}

Volume 5

Issue 1 Volume 5.1 (Spring 2015)

Article 3

2015

\title{
The Puzzling Origin of the Acquaintance between Charlotte Lennox and Thomas Birch
}

Patricia L. Hamilton

Union University, phamilto@uu.edu

Follow this and additional works at: https://digitalcommons.usf.edu/abo

Part of the Dramatic Literature, Criticism and Theory Commons, Educational Methods Commons, and the Feminist, Gender, and Sexuality Studies Commons

\section{Recommended Citation}

Hamilton, Patricia L. (2015) "The Puzzling Origin of the Acquaintance between Charlotte Lennox and Thomas Birch," ABO: Interactive Journal for Women in the Arts, 1640-1830: Vol.5: Iss.1, Article 3. http://dx.doi.org/10.5038/2157-7129.5.1.8

Available at: https://digitalcommons.usf.edu/abo/vol5/iss1/3

This Notes and Discoveries is brought to you for free and open access by Digital Commons @ University of South Florida. It has been accepted for inclusion in ABO: Interactive Journal for Women in the Arts, 1640-1830 by an authorized administrator of Digital Commons @ University of South Florida. For more information, please contact digitalcommons@usf.edu. 


\title{
The Puzzling Origin of the Acquaintance between Charlotte Lennox and Thomas Birch
}

\author{
Abstract \\ Scholars have puzzled over the origin of the relationship between Charlotte Lennox and Thomas Birch. \\ That the two shared a cordial professional relationship in 1759 is not surprising, but it is unclear how and \\ when Birch obtained the poem "The Dream, an ode by Miss Ramsey of 15" (ca. 1744-45) for his \\ manuscript collection. Possibly Edward Cave, publisher of The Gentleman's Magazine, or other \\ professional associates such as Samuel Johnson or Samuel Richardson supplied it. But archival evidence \\ indicates that Lady Isabella Finch, Lennox's earliest patroness, was in contact with Birch in 1749, raising \\ the question of whether she could have given Birch the poem. However, a different type of connection \\ between Lennox and Birch is suggested by Lennox's first novel, The Life of Harriot Stuart, written by \\ Herself (1750), which mentions William Chillingworth, Isaac Barrow, and John Tillotson as theological \\ influences. Lennox may have known of these three seventeenth-century divines through Birch's \\ biographical work on them.
}

\section{Keywords}

Charlotte Lennox, Thomas Birch, Lady Isabella Finch, William Chillingworth, Edward Cave

\section{Creative Commons License}

(c) $($ ) $\odot$

This work is licensed under a Creative Commons Attribution-No Derivative Works 3.0 License. 
In March 1759, Charlotte Lennox wrote to Thomas Birch to thank him for an unspecified "agreeable present" and to solicit support for her current writing project (Schürer 95-96). An ordained clergyman, Birch was fifty-three years old and had published widely as a biographer, both as the principal editor of the English edition of the General Dictionary, Historical and Critical, Pierre Bayle's landmark work, and as author of or collaborator on a variety of other projects. A supporter of women's writing, Birch had prepared a subscription edition of The Works of Mrs. Catharine Cockburn for publication (1751) and had written biographical sketches of various learned women, including Anna Maria van Schurman and Elizabeth Singer Rowe. Lennox, who was about thirty in 1759, had published a volume of poems, three novels, a work of Shakespeare criticism, and three translations. It is not surprising that the two successful literary figures were known to one another at this point in their respective careers. As A. E. Gunther, Birch's biographer, notes, Birch made a point of keeping abreast of the publishing world, especially after Philip Yorke, the eldest son of Lord Chancellor Hardwicke, commissioned him to write a weekly newsletter on the London literary scene during the summer season, starting in 1741 (38). Birch's correspondence shows that he functioned in a similar capacity during the same period for John Boyle, the fifth Earl of Orrery, one of Lennox's collaborators. Literary figures Birch numbered among his personal acquaintance included Elizabeth Carter, James Thomson, Richard Savage, Walter Harte, Samuel Johnson, Catherine Talbot, Samuel Richardson, Henry Fielding, David Garrick, and Colley Cibber.

Nonetheless, critics have puzzled over the origin of the Lennox-Birch relationship. Archival evidence shows that Birch was aware of Lennox as early as 1753. A letter to Yorke dated 23 June of that year discusses her newly published Shakespeare Illustrated (Schürer 49 n. 8). ${ }^{2}$ More intriguing than this, however, is that Birch's manuscript collection contains a poem labeled "The Dream, an ode by Miss Ramsey of 15" along with a version in Latin, both in Lennox's hand (BL Add MS 4456). Lennox would have been fifteen in 1744-45, having been sent to London sometime after the death of her father, James Ramsay, in New York on 10 March 1742. From the ode and its translation, Philippe Séjourné has surmised that Birch may have tutored Lennox in Latin (17) since it is not likely that Lennox composed the Latin version herself, given its sophistication (18). However, the only evidence that Séjourné adduces for a tutoring relationship is the BirchLennox correspondence of 1759, fourteen years later (18). Formal tutoring between Birch and Lennox would have been unlikely. ${ }^{3}$ Birch was fully occupied in the mid-1740s with ongoing literary and biographical projects along with clerical duties and meetings of the various learned societies to which he belonged. If the Latin translation was not entirely Lennox's own, someone besides Birch could have assisted her with it. 
Still, Birch's possession of the ode raises the question of how far back his personal acquaintance with Lennox dates. Birch seems to have been particularly interested in the early productions of literary women of his acquaintance. He kept copies of and circulated several of Elizabeth Carter's early letters in Latin (Ruhe 498; Hampshire 24), and he possessed copies of letters that Catherine Talbot wrote on literary topics as a teenager (Myers 66). Perhaps Birch obtained his copy of Lennox's poem through a professional associate who knew he collected examples of female genius. Edward Cave, with whom Birch had been associated since the late 1730s, printed one of Lennox's published poems along with a birthday ode she wrote for the Princess of Wales in The Gentleman's Magazine of November 1750 (Small 8). Perhaps Cave also had a copy of Lennox's "The Dream" and passed it along to Birch. Equally plausibly, Samuel Johnson or Samuel Richardson could have come into possession of the poem and given it to Birch.

Another possibility is that Birch received the copy of Lennox's poem from one of Lennox's intimates. At this point in Lennox's life her patronesses were Lady Isabella Finch, first Lady of the Bedchamber to Princess Amelia, and Lady Isabella's sister, Lady Rockingham. In 1761, Birch was appointed as Princess Amelia's chaplain, an event that occasioned a brief flurry of correspondence from Lady Isabella, who functioned as the Princess's secretary. But a letter from Finch to Birch written in 1752 attests that the two knew each other earlier (BL Add MS 4307). In fact, letters from clergyman Henry Etough to Birch in 1749 indicate that Lady Isabella not only was in contact with Birch but also was actively engaged in soliciting subscriptions for his edition of Catharine Cockburn's Works (Bigold 154). The question is, were Birch and Lady Isabella personally acquainted as early as 1744-45, when Lennox composed "The Dream"? And if so, could Lady Isabella have spoken to Birch about her protégée or given him a copy of the poem?

While such possibilities captivate the imagination, no evidence has yet surfaced that would either confirm or deny a direct relation between Lennox and Birch circa 1744-1747. Birch cultivated a vast acquaintance, but his diary suggests he tended to socialize among several fixed sets, including the Yorke household's weekly breakfasts starting in 1740 (Gunther 37) and, later on, Matthew Maty's Thursday Tea Club (Gunther 53). Because there is such a dearth of factual information about Lennox's life in the mid-1740s, it appears next to impossible to map her movements within Lady Isabella's or Lady Rockingham's social circles, much less to determine whether the Finch and Rockingham circles intersected at any point with the many in which Birch moved. But however tenuous the notion of a personal connection between Birch and Lennox might seem during Lennox's adolescence, a connection of another kind may have been possible. This becomes 
apparent when we change the question from when Birch first knew of Lennox to when Lennox first knew of Birch.

In her first novel, The Life of Harriot Stuart, Written by Herself (1750), Lennox mentions three seventeenth-century Anglican divines: William Chillingworth, Isaac Barrow, and John Tillotson. Birch not only wrote General Dictionary biographies of all three clerics but also published the Life of Chillingworth in 1742. He went on to publish the Life of Tillotson in 1752. Gunther speculates that Birch felt a particular affinity to Tillotson, who was Archbishop of Canterbury from 1691 to 1694, because Tillotson's migration from Puritanism to Anglicanism mirrored Birch's own journey from Quakerism to Anglicanism (24). Tillotson, in his turn, had been influenced by Chillingworth, author of the 1638 treatise, The Religion of Protestants a Safe Way of Salvation. Chillingworth had converted to Roman Catholicism at Oxford, then later reconverted to Protestantism. The chain of influence suggested by all these conversions becomes highly significant when we consider that Dumont, the heroine's love interest in Harriot Stuart, is converted from Roman Catholicism to Protestantism by reading Chillingworth (Lennox, Harriot Stuart 180).

The question that arises at this juncture is how Lennox, who was only twenty when Harriot Stuart was published, came to be acquainted with Barrow, Tillotson, and especially Chillingworth. Had she read the texts of Tillotson's and Barrow's sermons and Chillingworth's The Religion of Protestants a Safe Way of Salvation herself, or was she merely familiar with these authors by reputation? If the former, how did she gain access to these texts? If the latter, by what means did she become familiar with these particular divines from the previous century?

The fact that Birch penned biographical material on Chillingworth, Barrow, and Tillotson seems too convenient to be dismissed out of hand as coincidence without further investigation. I would suggest two possible avenues for future inquiry. 1) If Birch interacted with the young Charlotte personally during the period of Lady Isabella's patronage, he certainly could have sparked her interest in the three seventeenth-century Anglican divines, and most especially Chillingworth, whose Life he had recently completed. Future archival research may confirm a direct connection between Birch and Lennox ca. 1745-1750. Such a connection would go a long way toward clearing up the mystery of Birch's possession of a copy of the fifteen-year-old Lennox's poem. 2) Lennox could have become familiar with Birch's Life of Chillingworth sometime prior to the publication of Harriot Stuart and drawn the idea for Dumont's conversion from it rather than from the Chillingworth text, which is a long, dense work in the scholastic tradition. ${ }^{4}$ Someone who had direct ties to Birch-such as Lady Isabella Finch or Samuel Johnson-or even someone who was merely familiar with his work could have recommended Birch's Life to Lennox. What we 
presently know of Lennox's early life is vexed by gaps and silences, but future archival research may uncover connections in Lennox's social or professional networks that shed light on questions related to Lennox's access to texts or define her theological influences and interests more precisely.

Ultimately, there may be no connection whatsoever between Lennox's theological predilections and Birch's having written biographical material about each of the three divines named in Harriot Stuart, but Birch's connection to Lady Isabella, his interest in young female literary prodigies, and his possession of the ode written by the young Lennox make the possibility of such a connection tantalizing. At the very least, the theological interests Birch and Lennox shared may have contributed to the cordial relationship we catch a glimpse of in Lennox's March 1759 letter to Birch.

\section{Notes}

I wish to thank Susan Carlile and Betty Schellenberg for generously sharing their ideas and expertise.

1. Because a record of Lennox's birth has never been discovered, her age must always be given as an approximation. Susan Carlile has narrowed the window for her birth date to sometime between 11 March 1729 and 9 March 1730 (112).

2. A copy of Lennox's 1752 novel, The Female Quixote, is listed in Birch's inventory of his library (BL Add MS 4252), but with no indication of either when he obtained it or when he drew up his inventory.

3. Birch is sometimes reckoned to have tutored Lord Hardwicke's sons. Gunther only suggests that Birch's close connection to Philip Yorke and his brothers might be accounted for if Birch served as their "informal tutor" on Sunday visits with the family (35). Their official tutor was Samuel Salter, a Cambridge clergyman (Yorke 101).

4. According to Gunther, "Chillingworth's Life . . gave Birch the opportunity of an objective analysis in theological terms of the conversion of a brilliant mind to Romanism and of its return to the Anglican church" (48).

\section{Works Cited}

Bigold, Melanie. Women of Letters, Manuscript Circulation, and Print Afterlives in the Eighteenth Century. New York: Palgrave Macmillan, 2013. Print. 
Birch, Thomas. "Romances and Novels." Add MS 4252, ff. 37-38. British Lib., London.

Carlile, Susan. "Expanding the Feminine: Reconsidering Charlotte Lennox's Age and The Life of Harriot Stuart." The Eighteenth-Century Novel 4 (2004): 103-134. Print.

Finch, Isabella. Letter to Thomas Birch. 28[?] July 1752. Add MS 4307, f. 52. British Lib., London.

Gunther, A. E. The Life of the Rev. Thomas Birch D. D., F. R. S., 1705-1766. Suffolk: Halesworth P, 1984. Print.

Hampshire, Gwen, ed. Elizabeth Carter, 1717-1806: An Edition of Some Unpublished Letters. Newark: U of Delaware P, 2005. Print.

Lennox, Charlotte. "The Dream, an Ode by Miss Ramsey of 15." Add MS 4456, ff. 98-99. British Lib., London.

-. The Life of Harriot Stuart, Written by Herself. Ed. and introd. Susan Kubica Howard. Madison, NJ: Fairleigh Dickinson UP, 1995. Print.

Myers, Sylvia Harcstark. The Bluestocking Circle: Women, Friendship, and the Life of the Mind in Eighteenth-Century England. Oxford: Clarendon P, 1990. Print.

Ruhe, Edward. "Birch, Johnson, and Elizabeth Carter: An Episode of 1738-39." PMLA 73.5 (1958): 491-500. Print.

Schürer, Norbert, ed. Charlotte Lennox: Correspondence and Miscellaneous Documents. Lewisburg, PA: Bucknell UP, 2012. Print.

Séjourné, Philippe. The Mystery of Charlotte Lennox, First Novelist of Colonial America. Aix-en-Provence: Publications Des Annales De La Faculté Des Lettres, n.s. 62, 1967. Print.

Small, Miriam Rossiter. Charlotte Ramsay Lennox: An Eighteenth-Century Lady of Letters. New Haven: Yale UP, 1935. Print.

Yorke, Philip C. The Life and Correspondence of Philip Yorke, Earl of Hardwicke, Lord High Chancellor of Great Britain. Vol. 1. Cambridge: Cambridge UP, 1913. Print. 